Revue bibliographique pour le domaine irano-aryen

\title{
Matthew P. Canepa, "Rival Images of Iranian Kingship and Persian Identity in Post-Achaemenid Western Asia"
}

\section{Vito Messina}

\section{(2) OpenEdition Journals}

Electronic version

URL: http://journals.openedition.org/abstractairanica/48282

DOI: 10.4000/abstractairanica.48282

ISBN: 1961-960X

ISSN: 1961-960X

Publisher:

CNRS (UMR 7528 Mondes iraniens et indiens), Éditions de l'IFRI

\section{Electronic reference}

Vito Messina, "Matthew P. Canepa, "Rival Images of Iranian Kingship and Persian Identity in PostAchaemenid Western Asia"', Abstracta Iranica [Online], Volume 40-41 | 2019, document 24, Online since 15 July 2019, connection on 17 April 2021. URL: http://journals.openedition.org/abstractairanica/ 48282 ; DOI: https://doi.org/10.4000/abstractairanica.48282

This text was automatically generated on 17 April 2021.

Tous droits réservés 


\title{
Matthew P. Canepa, "Rival Images of Iranian Kingship and Persian Identity in Post-Achaemenid Western Asia"
}

\author{
Vito Messina
}

\section{REFERENCES}

Matthew P. Canepa, "Rival Images of Iranian Kingship and Persian Identity in PostAchaemenid Western Asia" in R. Strootman, M. J. Versluys (eds). Persianism in Antiquity. (Oriens et Occidens 25), Stuttgart: Franz Steiner Verlag, 2017, p.201-222

1 In this article, royal identities in post-Achaemenid Asia are explored by focusing on the role that images and rituals of power did play in claiming the legacy of the Achaemenids. In spite of the paucity of evidence, the Author envisages new forms of royal power that engaged both Iranian and Macedonian cultures of kingship. In his opinion, documents are ample enough to infer the rise and pre-eminence of Parthian court culture in the Iranian world, and to postulate that the Arsacids did produce a new culture of Iranian kingship that challenged that of the Seleucids. This must be of course contextualized in a frame that di see different responses to the Persian and Macedonian royal legacies in the different regions of what was the Persian Empire. These 'alternative visions' of post-Achaemenid kingship could have become dominant and have rivalled those of the Arsacids, with sovereigns who presented powerful alternative visions of a new post-Achaemenid Iranian kingship. 


\section{AUTHORS}

VITO MESSINA

Università di Torino 